\title{
Pulmonary deposition of nebulised pentamidine isethionate: effect of nebuliser type, dose, and volume of fill
}

Michael O'Doherty, Simon Thomas, Christopher Page, Caroline Bradbeer, Tom Nunan, Nigel Bateman

Abstract

An estimate of the absolute pulmonary deposition of nebulised pentamidine isethionate was obtained in nine patients with AIDS. Two nebuliser systems were compared, System 22 Mizer (Medic-Aid) and Respirgard II (Marquest), with 50 and $150 \mathrm{mg}$ doses of pentamidine in a $3 \mathrm{ml}$ solution driven by an air flow of 6 $1 / \mathrm{min}$ with the patient in the sitting position. The $50 \mathrm{mg}$ pentamidine dose was repeated with a $6 \mathrm{ml}$ fill with both devices. The nebuliser cloud was labelled with technetium-99m human serum albumin (Ventocol) and lung deposition was measured with a gamma camera. Of the two nebulisers studied, System 22 Mizer delivered more drug to the lungs as $a$ whole and to each individual lung region, including the peripheral and upper zones. For the $50 \mathrm{mg}$ dose the mean (SEM) total pulmonary deposition with the 3 and the $6 \mathrm{ml}$ fill respectively was $2.63(0.34)$ and $3.71(0.41) \mathrm{mg}$ for the System 22 Mizer and $1.37(0.26)$ and 1.45 $(0.18) \mathrm{mg}$ for the Respirgard II. For the $150 \mathrm{mg}$ dose the System 22 Mizer delivered $7 \cdot 16(1.02) \mathrm{mg}$ and the Respirgard II $4.34(0.57) \mathrm{mg}$. Increasing the volume of fill from 3 to $6 \mathrm{ml}$ increased pulmonary deposition with System 22 Mizer, and this was related to an increase in nebuliser output. Neither pulmonary deposition nor nebuliser output was increased by using a $6 \mathrm{ml}$ solution in the Respirgard II. Increasing the volume of fill prolonged the time required for nebulisation with both nebulisers. The System 22 Mizer produced more nonpulmonary (gastric and oropharyngeal) deposition of drug, more frequent local adverse effects (cough, burning in the throat, and a metallic taste), and small reductions in lung function, particularly with the $150 \mathrm{mg}$ pentamidine dose. Thus nebuliser type, volume of fill, and nebuliser dose affect the pulmonary deposition of pentamidine. A $300 \mathrm{mg}$ dose of pentamidine via a Respirgard II is generally recommended as providing effective prophylaxis; our results suggest that similar pulmonary deposition can be produced with System 22 Mizer and $150 \mathrm{mg}$ pentamidine. A clinical trial would be needed to show whether this regimen provides similar prophylactic benefit.
The administration of antimicrobial agents via the respiratory tract has been successful in the treatment of lung infections. ${ }^{1-4}$ Nebulised pentamidine isethionate is effective in the treatment of acute Pneumocystis carinii pneumonia and in the suppression of disease recurrence. In centres conducting clinical trials of nebulised pentamidine to treat pneumocystis pneumonia or as prophylaxis against it the nebuliser system, dose of pentamidine, and volume of nebuliser fill have varied..$^{5-7}$ As the therapeutic benefit of nebulised pentamidine is assumed to depend on local deposition in the lungs, the amount reaching different parts of the lung must be measured before we can interpret the results of clinical studies.

Many factors alter pulmonary aerosol deposition. The output of a nebuliser varies with the flow rate of the driving gas, the volume of solution used, and the drug concentration and temperature of the solution being nebulised; measurements of the dose of drug in the nebuliser cloud, however, will not reliably predict the dose of drug reaching and remaining in the lungs because this may be altered by the respiratory pattern of the patient and by the inhalation apparatus. It will not be surprising if trials of nebulised pentamidine using different nebulisers, doses, and operating conditions produce different results, and these can be interpreted only when measurements of pentamidine deposition in the lung have been made.

In this study we report the pulmonary deposition of pentamidine administered in two different doses via two suitable nebuliser systems. As the volume of fluid placed in the nebuliser will affect nebuliser output, ${ }^{8}$ the $50 \mathrm{mg}$ dose was also given in a larger volume of fluid. The doses, volume of nebuliser solution, and nebulisers we chose correspond to those that are best tolerated or deliver the largest dose to the lung. ${ }^{9-11}$

\section{Methods}

Nine patients with AIDS, eight with previous pneumocystis pneumonia and one with Kaposi's sarcoma, took part in the study, which was approved by the ethical committee of West Lambeth Health District. All gave informed consent before participation. Pulmonary deposition of pentamidine was measured on six separate occasions in each patient, the nebuliser doses being $50 \mathrm{mg}$ ( 3 and $6 \mathrm{ml}$ dilutions $)$ and $150 \mathrm{mg}(3 \mathrm{ml} \mathrm{dilu-}$ 
tion), administered with a system 22 Mizer (Medic-Aid) and a Respirgard II (Marquest) nebuliser, each driven by compressed air at $6 \mathrm{l} / \mathrm{min}$.

Doses of pentamidine and nebuliser systems were assessed in random order. Nebulised salbutamol was administered before inhalation of pentamidine and lung function tests (forced expiratory volume in one second $\left(F_{1} V_{1}\right)$, forced vital capacity (FVC), peak expiratory flow (PEF)) were performed before and after the salbutamol and after administration of nebulised pentamidine.

The nebuliser solution was labelled with a standard dose of $37 \mathrm{MBq}$ of technetium-99m human serum albumin ( ${ }^{99 \mathrm{~m}}$ Tc HSA, Ventocol) in a concentration of $16.6 \mu \mathrm{g} / \mathrm{ml}$ for both the 3 and the $6 \mathrm{ml}$ nebuliser volumes. The binding efficiency of the ${ }^{99 \mathrm{~m}} \mathrm{Tc}$ HSA was assessed by paper chromatography of the nebuliser solution and the aerosol cloud. ${ }^{12}$ Particle sizes in the aerosol cloud were measured for the 3 and $6 \mathrm{ml}$ volumes with three System 22 and three Respirgard II nebulisers with a Malvern 2600 laser.

The total outputs (cloud recovery) of four System 22 and four Respirgard II nebuliser units were measured with ${ }^{99 m}$ Tc HSA by nebulising the solution to dryness. This was performed with 3 and $6 \mathrm{ml}$ volumes for the $50 \mathrm{mg}$ dose of pentamidine. The nebuliser cloud was captured with a pre-impinger, which is a coarse filter for removing larger particles, and an "absolute" filter, which removes the smaller particles. The total quantity of pentamidine in the nebuliser cloud was determined by washing the pre-impinger and absolute filters with known quantities of distilled water and measuring the absorbance (wavelength $266 \mathrm{~nm}$ ) of this solution, diluted in such a way that the absorbance did not saturate the spectrometer. Previous investigations have shown absorbance to be linearly related to pentamidine concentration, and the absorbance of a $1 \%$ solution measured in a $1 \mathrm{~cm}$ silicon cuvette was $469 \cdot 6 .^{12}$

In each study the patients remained seated with their backs to a gamma camera (large field of view IGE Maxi II) with a high sensitivity collimator for the 20 ( $3 \mathrm{ml}$ fill) or $40 \mathrm{~min}(6 \mathrm{ml}$ fill) period of aerosol inhalation. Movement of the patient was prevented by using a fixed seat with side restraints preventing lateral movement, and by fixing the position of the nebuliser mouthpiece in the midline of the gamma camera. Dynamic pulmonary deposition (posteroanterior view) was

Table 1 Nebuliser activity before and after nebulisation: mean (SEM) results from nine experiments

\begin{tabular}{|c|c|c|c|c|}
\hline \multirow[b]{2}{*}{ Volume in nebuliser } & \multicolumn{2}{|c|}{ System 22 Mizer } & \multicolumn{2}{|c|}{ Respirgard II } \\
\hline & $3 \mathrm{ml}$ & $6 \mathrm{ml}$ & $3 \mathrm{ml}$ & $6 \mathrm{ml}$ \\
\hline $\begin{array}{l}\text { Nebuliser activity }(\mathrm{MBq}) \\
\text { Initial (before nebulisation) } \\
\text { Final (after nebulisation) } \\
\text { Initial - final } \\
\%_{1} \text { output }\end{array}$ & $\begin{array}{l}40.4(0 \cdot 7) \\
25.9(0 \cdot 7) \\
14 \cdot 7(0 \cdot 7) \\
36 \cdot 1(1 \cdot 6)\end{array}$ & $\begin{array}{l}40 \cdot 5(0 \cdot 6) \\
20 \cdot 4(0 \cdot 8) \\
20 \cdot 1(0 \cdot 8)^{\star} \\
49 \cdot 6(2 \cdot 1)\end{array}$ & $\begin{array}{l}40.6(0.6) \\
21.9(0.9) \\
18 \cdot 7(0.9) \\
46 \cdot 1(2 \cdot 3)\end{array}$ & $\begin{array}{l}40.9(0.85) \\
20 \cdot 2(1.0) \\
20 \cdot 7(0.9) \\
49 \cdot 4(2 \cdot 1)\end{array}$ \\
\hline
\end{tabular}

${ }^{\star} \mathrm{p}<0.001$ for $3 \mathrm{ml} v 6 \mathrm{ml}$ volume in nebuliser. measured in 15 second counting frames. On completion of the treatment static images of the lungs (anterior and posterior) abdomen (anterior and posterior), oropharynx (right lateral head and neck), and inhalation apparatus were acquired over 100 seconds. Radioactivity associated with the nebuliser was measured both with an ionisation chamber and with the gamma camera before and after nebulisation. A xenon-133 equilibrium scan was obtained for each subject on one occasion. This was used to define the lung outline (with the $20 \%$ maximum count contour), lung thirds (dividing the lung horizontally into three parts of equal height), and central and peripheral lung regions (the central region was defined as a rectangle over the middle third of the medial border, extending half way across the lung). Pentamidine deposition was assessed in these regions and a penetration index derived by dividing the ${ }^{99 m}$ Tc HSA counts by the ${ }^{133} \mathrm{Xe}$ counts in the central and peripheral lung regions ([central HSA/peripheral HSA]/[central Xe/peripheral $\mathrm{Xe]}$ ). The right peripheral lung was used for estimations of peripheral pentamidine deposition as it avoids aerosol deposited in large central airways, stomach, and oesophagus.

A lung phantom method $^{13}$ was used to enable estimates of absolute deposition to be obtained. A perspex cylinder, $3 \mathrm{~cm}$ deep and $30 \mathrm{~cm}$ in diameter, was filled with a solution containing $37 \mathrm{MBq}$ of ${ }^{99 \mathrm{~m}} \mathrm{Tc}$ and pentamidine 50 or $150 \mathrm{mg}$. The cylinder was placed $10 \mathrm{~cm}$ in front of the gamma camera with a single tissue equivalent disc, $40 \mathrm{~cm}$ in diameter and $1 \mathrm{~cm}$ thick, placed on the surface of the camera. An equivalent amount of activity in both types of nebuliser was measured for the same time as in the phantom. The geometric factor (required to convert patient measurements to absolute lung values) was calculated by comparing the ratio of counts obtained for both volumes of fill.

Statistical comparisons were performed by means of the non-parametric Wilcoxon rank sum test, which was applied to all paired data.

\section{Results}

The ${ }^{99 \mathrm{~m}} \mathrm{Tc}$ remained bound to the human serum albumin in the pentamidine solution and in the aerosol cloud (less than $2 \%$ free technetium). The mass median diameters of particles produced by the System 22 Mizer and Respirgard II respectively were 3.7 (span $2 \cdot 0$ ) $\mu \mathrm{m}$ and $2.0(1.6) \mu \mathrm{m}$ with the $3 \mathrm{ml}$ nebuliser volume, and $3.6(1.9) \mu \mathrm{m}$ and $2 \cdot 2(1.6) \mu \mathrm{m}$ with the $6 \mathrm{ml}$ volume. When expressed as a percentage of the nominal nebuliser dose $(50 \mathrm{mg}$ ) cloud recovery for the 3 and $6 \mathrm{ml}$ volumes respectively was $40 \%$ (SEM 3\%) and $61 \%$ $(1 \%)$ for the System 22 Mizer and $28 \%(3 \%)$ and $32 \%(1 \%)$ for the Respirgard II.

The activities (counts per second from the ${ }^{99} \mathrm{~m} \mathrm{Tc}$ ) in the System 22 Mizer and Respirgard II nebuliser units (excluding the inhalation apparatus) before and after nebulisation are shown in table 1 . With the $3 \mathrm{ml}$ volume more activity was lost from the Respirgard II nebu- 


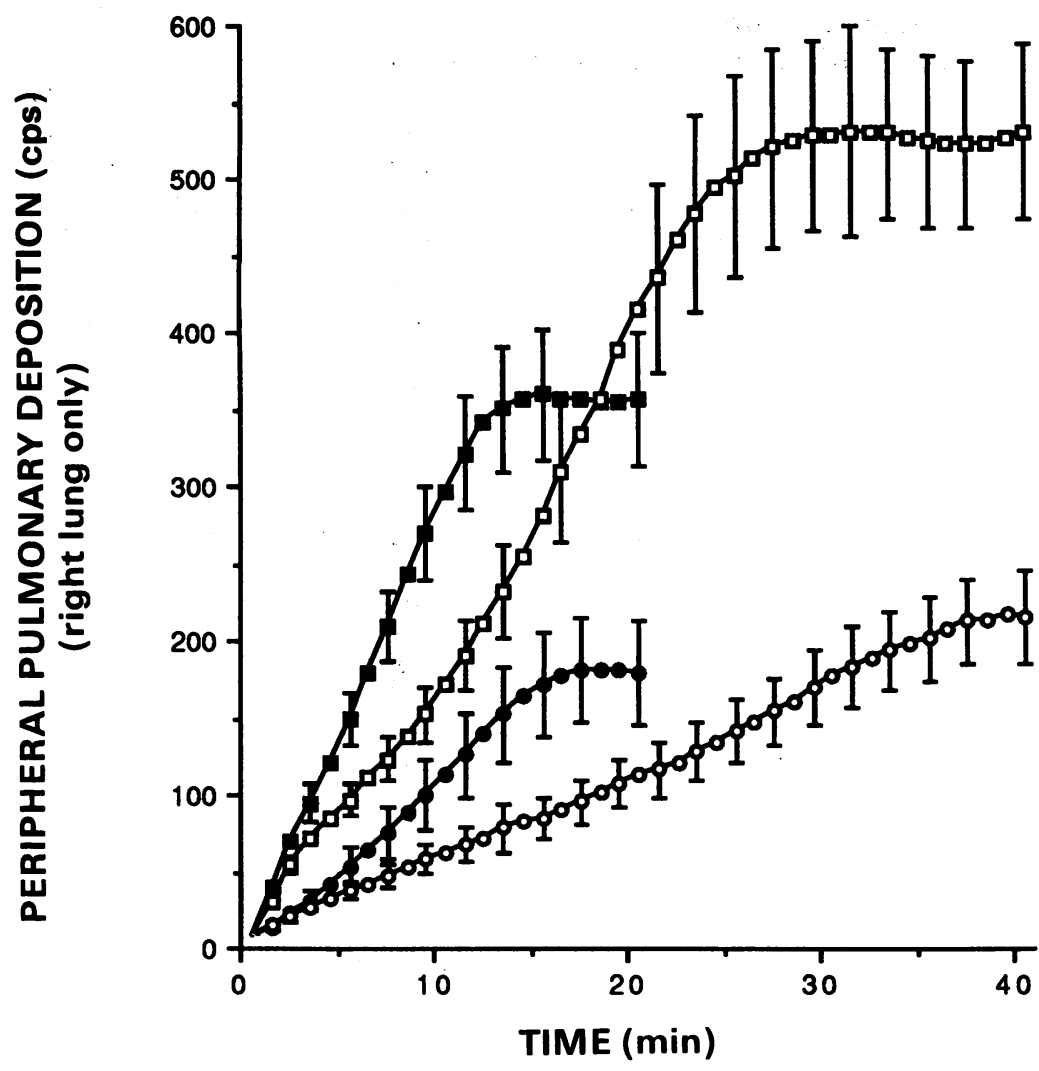

Dynamic deposition curves in right peripheral lung (counts per second, cps) with 3 and $6 \mathrm{ml}$ fills containing $50 \mathrm{mg}$ pentamidine: mean (SEM) results for nine patients.

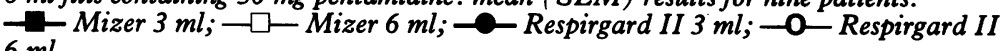

liser $(\mathrm{p}<0.01)$. With the System 22 Mizer the activity lost from the nebuliser increased substantially from 14.7 to $20 \cdot 1 \mathrm{MBq}(\mathrm{p}<0.001$ ) when the volume was increased from 3 to $6 \mathrm{ml}$; no significant change was observed with the Respirgard II. These changes are in keeping with the in vitro work.

The accumulation of pentamidine in peripheral lung during inhalation of aerosol is shown in the figure. Values are expressed in counts per second (cps) as a geometric correction is not possible because only posteroanterior dynamic images of the lung were obtained. The curves show that pentamidine is delivered more rapidly, and deposition completed earlier with the System 22 Mizer. Increasing the volume in the nebuliser reduced the rate and increased the time taken for maximum deposition to occur. The total time taken for maximum deposition of $50 \mathrm{mg}$ pen- tamidine to occur with the System 22 Mizer and Respirgard II nebulisers were 12 and 17 minutes for the $3 \mathrm{ml}$ volume and 27 and 37 minutes for the $6 \mathrm{ml}$ volume. The time course of deposition of the $150 \mathrm{mg}$ dose was similar to that of the $50 \mathrm{mg}$ dose for the $3 \mathrm{ml}$ solution volume (data not shown). The rate of deposition in the lung was measured as the slope of the activity time curve. This remains relatively constant for both nebulisers with the $3 \mathrm{ml}$ fill, but the rate of deposition increases with time when the $6 \mathrm{ml}$ fill is used with Respirgard II, from 0.09 (SEM 0.02) $\mathrm{cps}^{-2}$ between 9 and 11 minutes to $0.17(0.02) \mathrm{cps}^{-2}(\mathrm{p}<0.01)$ between 24 and 26 minutes. A similar effect is seen with System 22 Mizer but is less important owing to the shorter nebulisation period.

Pulmonary deposition of nebulised pentamidine is shown in table 2. Deposition in the lungs as a whole and in each lung region was greater with the higher pentamidine dose with both nebulisers. At each dose and volume of solution the nebuliser volume deposition in all regions was larger with the System 22 Mizer than with the Respirgard II ( $p<0.05)$. With the right peripheral lung used as a measure of pentamidine delivery to its site of action, deposition with the System 22 Mizer was greater for $50 \mathrm{mg}$ in $3 \mathrm{ml}(\mathrm{p}<0.001), 50 \mathrm{mg}$ in $6 \mathrm{ml}(\mathrm{p}<0.001)$, and $150 \mathrm{mg}$ in $3 \mathrm{ml}$ $(\mathrm{p}<0.05)$ than for the same doses and nebuliser volumes with the Respirgard II. With both nebulisers deposition in the upper third of the lung was less than in the lower third, even when differences in lung volume are allowed for. Increasing the volume of fill from 3 to $6 \mathrm{ml}$ increased pentamidine deposition in all lung regions with System 22 Mizer, for the right peripheral lung region by $37 \%(p<0.005)$. No statistically significant increases were seen with Respirgard II.

The ratio of central to peripheral aerosol deposition, corrected for differences in regional lung volume on the basis of data from the ${ }^{133} \mathrm{Xe}$ scan, acts as an index of aerosol penetration, high values indicating greater central deposition (table 3). For both pentamidine doses this penetration index was lower for Respirgard II than for System 22 Mizer, indicating superior peripheral aerosol penetration (closer to the distribution of gas within the lung), but the difference was significant only for the $50 \mathrm{mg}$ pentamidine dose $(\mathrm{p}<0.05)$.

Table 2 Estimated absolute pulmonary deposition of pentamidine for two doses and two volumes in the nebuliser: (SEM) results from nine patients

\begin{tabular}{|c|c|c|c|c|c|c|}
\hline \multirow{2}{*}{$\begin{array}{l}\text { Pentamidine dose }(\mathrm{mg}): \\
\text { Volume in nebuliser }(\mathrm{ml}) \text { : }\end{array}$} & \multicolumn{3}{|c|}{ System 22 Mizer } & \multicolumn{3}{|c|}{ Respirgard II } \\
\hline & $\begin{array}{r}50 \\
3\end{array}$ & $\begin{array}{r}50 \\
6\end{array}$ & $\begin{array}{r}150 \\
3\end{array}$ & $\begin{array}{r}50 \\
3\end{array}$ & $\begin{array}{r}50 \\
6\end{array}$ & $\begin{array}{r}150 \\
3\end{array}$ \\
\hline \multicolumn{7}{|c|}{$\begin{array}{l}\text { Absolute pentamidine deposition } \\
\text { (mg) }\end{array}$} \\
\hline $\begin{array}{l}\text { Total } \\
\text { Left lung } \\
\text { Right lung } \\
\text { Right peripheral lung } \\
\text { Right upper lobe } \\
\text { Right lower lobe }\end{array}$ & $\begin{array}{l}2.63(0.34)^{\star} \\
1.21(0.16)^{\star} \\
1.42(0.14)^{\star} \\
1.08(0.14)^{\star} \\
0.35(0.18)^{\star} \\
0.50(0.08)^{\star}\end{array}$ & $\begin{array}{l}3.71(0.41)^{\star} \dagger \\
1.69(0.20)^{\star} \dagger \\
2.02(0.23)^{\star} \dagger \\
1.48(0.17)^{\star} \dagger \\
0.41(0.05)^{\star} \dagger \\
0.85(0.13)^{\star} \dagger\end{array}$ & $\begin{array}{l}7.16(1.02)^{\star} \\
3.39(0.50)^{\star} \\
3.77(0.55)^{\star} \\
2.79(0.42)^{\star} \\
0.81(0.14)^{\star} \\
1.37(0.23)^{\star}\end{array}$ & $\begin{array}{l}1.37(0.26) \\
0.63(0.14) \\
0 \cdot 74(0.15) \\
0 \cdot 58(0.11) \\
0.16(0.03) \\
0.29(0.05)\end{array}$ & $\begin{array}{l}1.45(0.18) \\
0.65(0.08) \\
0.81(0.11) \\
0.62(0.09) \\
0.16(0.03) \\
0.31(0.05)\end{array}$ & $\begin{array}{l}4.34(0.63) \\
1.92(0.26) \\
2.41(0.38) \\
2.00(0.34) \\
0.60(0.16) \\
0.98(0.19)\end{array}$ \\
\hline
\end{tabular}

${ }^{\star} \mathrm{p}<0.05$ for System 22 Mizer $v$ Respirgard II with the same dose and volume in nebuliser.

tp $<0.05$ for $3 \mathrm{ml} v 6 \mathrm{ml}$ volume in nebuliser with the same dose and nebuliser. 
Table 3 Non-pulmonary deposition and penetration index (see text) for two pentamidine doses and volumes in nebuliser: mean (SEM) results from nine patients

\begin{tabular}{|c|c|c|c|c|c|c|}
\hline \multirow[b]{2}{*}{$\begin{array}{l}\text { Pentamidine dose ( } \mathrm{mg}) \text { : } \\
\text { Volume in nebuliser }(\mathrm{ml}) \text { : }\end{array}$} & \multicolumn{3}{|l|}{ System 22 Mizer } & \multicolumn{3}{|l|}{ Respirgard II } \\
\hline & $\begin{array}{r}50 \\
3\end{array}$ & $\begin{array}{r}50 \\
6\end{array}$ & $\begin{array}{r}150 \\
3\end{array}$ & $\begin{array}{r}50 \\
3\end{array}$ & $\begin{array}{r}50 \\
6\end{array}$ & $\begin{array}{r}150 \\
3\end{array}$ \\
\hline $\begin{array}{l}\text { Pentamidine deposition (c } \\
\text { Oropharynx } \\
\text { Stomach } \\
\text { Exhalation filter } \\
\text { Apparatus }\end{array}$ & $\begin{array}{c}145(27) \dagger \\
222(51) \dagger \\
1883(279) \dagger \\
1983(266) \dagger\end{array}$ & $\begin{array}{l}237(25) \dagger \ddagger \\
502(97) \dagger \ddagger \\
3631(270) \dagger \ddagger \\
2298(207) \dagger\end{array}$ & $\begin{array}{c}86(27) \dagger \\
394(52) \dagger \\
1843(230) \dagger \\
2014(218) \dagger\end{array}$ & $\begin{array}{c}55(11) \\
18(4) \\
3216(407) \\
4620(493)\end{array}$ & $\begin{array}{c}43(8) \\
25(6) \\
4721(669) \ddagger \\
3628(257)\end{array}$ & $\begin{array}{c}32(5) \\
75(35) \\
3339(951) \\
4604(605)\end{array}$ \\
\hline Penetration index ${ }^{\star}$ & $2.87(0.68) \dagger$ & $2.52(0.62)$ & $3.06(0.93)$ & $1.73(0.46)$ & $1.73(0.37)$ & $1.85(0.41)$ \\
\hline
\end{tabular}

«Ratio of central to peripheral aerosol deposition corrected for differences in regional lung volume—see under "Methods."

tp $<0.05$ for System 22 Mizer $v$ Respirgard II with the same dose and volume in nebuliser.

$\ddagger \mathrm{p}<0.05$ for $3 \mathrm{ml} v 6 \mathrm{ml}$ in nebuliser with the same dose and nebuliser.

Non-pulmonary deposition of pentamidine is shown in table 3. Deposition in the stomach and oropharynx was larger with the System 22 Mizer for both doses of pentamidine $(p<$ 0.01 ). Deposition on the inhalation apparatus (excluding the nebuliser itself) was greater for Respirgard II ( $\mathrm{p}<0.001$ ), with most activity located in the region of the inspiratory valve. For the System 22 Mizer, increasing the volume in the nebuliser from 3 to $6 \mathrm{ml}$ increased deposition in the stomach and oropharynx, but even so local adverse effects (cough and burning in the throat) were less troublesome. Deposition in the exhalation filter with the $3 \mathrm{ml}$ volume was greater with the Respirgard II ( $p<0.01$ ) and was increased with the $6 \mathrm{ml}$ volume with both nebulisers $(\mathrm{p}<0.05)$.

The results of lung function tests are shown in table 4. The reductions in $\mathrm{FEV}_{1}$, forced vital capacity, and peak expiratory flow were larger with the $150 \mathrm{mg}$ pentamidine dose and with the System 22 Mizer when the $3 \mathrm{ml}$ nebuliser volume was used, though the differences were small and unlikely to be of clinical importance. Adverse effects were more frequent with the higher pentamidine dose and the System 22 Mizer; none was severe, however, and all patients were able to tolerate both the 50 and the $150 \mathrm{mg}$ doses of pentamidine with both nebulisers.

\section{Discussion}

Nebulised pentamidine is used as a site specific treatment to prevent the recurrence of pneumocystis pneumonia, and has a low in-

Table 4 Lung function tests: mean ( $S D$ ) results from nine patients

\begin{tabular}{|c|c|c|c|c|c|}
\hline & $\begin{array}{l}\text { Dose } \\
\text { (mg) }\end{array}$ & $\begin{array}{l}\text { Volume of } \\
\text { fill }(\mathrm{ml})\end{array}$ & $F E V_{1}(l)$ & $F V C(l)$ & $P E F(l / \min )$ \\
\hline $\begin{array}{l}\text { Before pentamidine } \\
\text { Before salbutamol } \\
\text { After Salbutamol }\end{array}$ & & & $\begin{array}{l}2.54(0.63) \\
2.61(0.65)\end{array}$ & $\begin{array}{l}3.47(1.06) \\
3.59(1.11)\end{array}$ & $\begin{array}{l}304(120) \\
329(104)\end{array}$ \\
\hline $\begin{array}{l}\text { After Pentamidine via } \\
\text { Respirgard II } \\
\text { System } 22 \text { mizer }\end{array}$ & $\begin{array}{r}50 \\
50 \\
150 \\
50 \\
50 \\
150\end{array}$ & $\begin{array}{l}3 \\
6 \\
3 \\
3 \\
6 \\
3\end{array}$ & $\begin{array}{l}2.51(0.54) \\
2.47(0.61) \\
2.49(0.61) \\
2.37(0.85)^{\star} \\
2.36(0.49)^{\star} \\
2.24(0.79)^{\star}\end{array}$ & $\begin{array}{l}3.47(1.07) \\
3.44(1.14) \\
3.31(0.97)^{\star} \\
3.34(1.45)^{\star} \\
3.23(1.13)^{\star} \\
3.07(1.12)^{\star} \dagger\end{array}$ & $\begin{array}{l}300(130) \\
301(129) \\
292(134)^{\star} \\
276(141)^{\star} \\
299(127) \\
270(132)^{\star}\end{array}$ \\
\hline
\end{tabular}

${ }^{\star} \mathrm{p}<0.05 v$ post-salbutamol value, with same dose and volume in nebuliser.

tp $<0.05$ System 22 Mizer $v$ Respigard II

FEV 1 -forced expiratory volume in one second; FVC-forced vital capacity; PEF-peak expiratory flow. cidence of systemic adverse effects even with high doses. Nebuliser treatment is time consuming, however, and reducing the nebulisation time by increasing the drug concentration or reducing the volume to be nebulised is appealing. Side effects are more frequent with high pentamidine concentrations, and small nebuliser fluid volumes reduce the efficiency of delivery. The "dead volume" of fluid that remains attached to the baffles and other internal components in the nebuliser is variable but may be as much as half of the initial volume. ${ }^{8}$ Thus pentamidine delivery must be measured for each nebuliser, dose of pentamidine, and initial nebuliser volume to ensure that adequate lung deposition is achieved. In the absence of radiolabelled pentamidine, a marker must be used that does not affect the output characteristics of the nebuliser and faithfully repoduces the movement of pentamidine in the aerosol cloud. Work from our own department ${ }^{12}$ and elsewhere ${ }^{14}$ suggests that ${ }^{99 \mathrm{~m}} \mathrm{Tc}$ HSA is suitable for this purpose.

Using this marker of pentamidine deposition and the methods described above we have studied the performance of the System 22 Mizer and Respirgard II nebulisers with two doses of pentamidine and two volumes in the nebuliser. The percentage deposition (total deposition/nebuliser dose $\times 100$ ) was from $2.7 \%$ to $2.9 \%$ with the Respirgard II, and from $4.6 \%$ to $7 \cdot 4 \%$ with the System 22 Mizer, depending on the dose and volume in the nebuliser. Under identical conditions of use the System 22 Mizer deposits $1 \cdot 6-2 \cdot 6$ times as much pentamidine in the lungs as does the Respirgard II. This is consistent with the greater retention of pentamidine in the inhalation apparatus and exhalation filter of the Respirgard II.

Increasing the volume in the nebuliser from 3 to $6 \mathrm{ml}$ increased the nebuliser output and the pulmonary deposition of pentamidine with the System 22 Mizer but not with the Respirgard II. A substantial increase in the nebulisation time was found with both nebulisers. The increasing slope of the activity-time curve during inhalation of $50 \mathrm{mg}$ pentamidine in $6 \mathrm{ml}$ solution via the Respirgard II suggests that pentamidine concentration in the nebuliser cloud increases with time. This could be caused by evaporation of water associated with the prolonged nebulisation period, resulting in concentration of drug in the "dead volume" 
and thus reducing the efficiency of the nebuliser. This effect is less pronounced with the smaller volume and the System 22 Mizer because of the short nebulisation periods required.

Non-pulmonary deposition, changes in lung function, and adverse effects were greater with the System 22 Mizer, but the nebuliser could be tolerated by all the subjects. The increased deposition in the upper respiratory tract and central lung region is to be expected in view of the larger aerosol particles. Adverse effects were less frequent with the higher volume of fill despite the increased deposition in the upper and lower respiratory tract. This suggests that these adverse effects are related to the concentration and rate of deposition of the pentamidine solution rather than the total dose delivered.

As the minimum lung dose of pentamidine giving adequate therapeutic or prophylactic response is not known, we must await the results of trials using different doses of pentamidine and different nebulisers before designing trials or recommending doses. Leoung et $a^{11}$ have shown that $150 \mathrm{mg}$ pentamidine twice monthly, or $300 \mathrm{mg}$ monthly, in $6 \mathrm{ml}$ solution nebulised via a Respirgard II nebuliser provides adequate prophylaxis against pneumocystis pneumonia. Our results suggest that this represents a lung dose of about $9 \mathrm{mg}$ each month. Similar lung doses can be achieved by nebulising lower doses of the drug via more efficient apparatus, such as the System 22 Mizer. This approach would be less costly and time consuming, but may be associated with more frequent local symptoms. Alternatively, if the same nebuliser dose of pentamidine were given via the System 22 Mizer, better prophylaxis may be achieved, particularly in view of its superior deposition in the upper lung, a common site for recurrence of pneumocystis pneumonia. Possibly other nebulisers or conditions of use would further improve pulmonary deposition and acceptability to patients.
We recommend that pulmonary pentamidine deposition is measured under the conditions used in the clinical trials currently in progress to allow a more informed comparison of their results. Knowledge of lung deposition is mandatory if the most appropriate dose, solution volume, and nebuliser for pentamidine administration are to be selected.

1 Hodson ME, Penketh ARC, Batten JC. Aerosol carbenicillin and gentamicin treatment of Pseudomonas aeruginosa infection in patients with cystic fibrosis. Lancet 1981; ii:1137-9.

2 Littlewood JM, Miller MG, Ghoneim AT, Ramsden CH Nebulised colomycin for early Pseudomonas colonisation in cystic fibrosis. Lancet $1985 ; \mathrm{i}: 865$.

3 Fitzgeorge RB, Baskerville A, Featherstone ASR. Treatment of experimental Legionnaire's disease by aeroso administration of rifampicin, ciprofloxacin, and erythromicin. Lancet 1986;i:502-3.

4 Bell M, Hunter JM, Mostafa SM. Nebulised ribavirin for influenza B viral pneumonia in a ventilated immunocompromised patient. Lancet 1988;ii:1084-5.

5 Leoung GS, Montgomery AB, Abrams DA, Korkery K, Wardlaw L, Feigel DW. Aerosol pentamidine for Pneumocystis carinii (PCP) pneumonia [abstract]. A ranPneumocystis carinii (PCP) pneumonia [abstract]. A ran-
domised trial of 439 patients. In: Proceedings of IVth domised trial of 439 patients. In: Proceedings of

6 Bernard EM, Schmitt HJ, Lifton A, Selzer M, Dickmeyer MS, Armstrong D. Prevention of Pneumocystis carini pneumonia with aerosolised pentamidine [abstract]. In: Proceedings of IVth International Conference on AIDS Stockholm, 1988.

7 Montgomery AB, Debs RJ, Luce JM, et al. Aerosolised pentamidine as sole therapy for Pneumocystis carinii in patients with the acquired immunodeficiency syndrome. Lancet 1987; ii:480-3.

8 Newman SP, Pellow PGD, Clay MM, Clarke SW. Evaluation of nebulisers for use with gentamicin solution. Thorax 1985;40:671-6.

9 Girard P-M, Landman R, Gaudebout C, et al. Prevention of Pneumocystis carinii pneumonia relapse by pentamidine Pneumocystis carinii pneumonia relapse by pentamidine aerosol in zidov

10 O'Doherty MJ, Thomas S, Page C, et al. Differences in the relative efficiency of nebulisers for pentamidine administration. Lancet 1988;ii:1283-6.

11 Leoung GS, Montgomery AB, Abrams DA, et al. Aerosol pentamidine for Pneumocystis carinii pneumonia: a $3 \mathrm{arm}$ randomised trial [abstract]. In: Proceedings of Vth International Conference on AIDS. Montreal, 1989.

12 O'Doherty MJ, Thomas S, Page C, et al. Particle characteristics of nebulised pentamidine isethionate solutions from istics of nebulised pentamidine isethionate solutions from different nebulisers with and without 9 \% 19 ch

13 Ruffin RE, Dolovitch MB, Wolff RK, Newhouse MT. The effects of preferential deposition of histamine in the effects of preferential deposition of histamine in
human airway. Am Rev Respir Dis 1978;117:485-91.

14 Smalldone GC, Perry RJ, Deutsch DG. Characteristics of nebulisers used in the treatment of AIDS related Pneumocystis carinii pneumonia. J Aerosol Med 1988;1: 113-26. 